\title{
Population genetic structure and genetic diversity study in Lallemantia royleana (Benth.) Benth.: identification of potential gene pools in Iran
}

\author{
Fahimed Koohdar ${ }^{1, *}$, Masoud Sheidai ${ }^{1}$ (D), Seyed Mehdi Talebi ${ }^{2}$
}

Key words: Gene flow, genetic fragmentation, ISSR, population assignment, Lallemantia.

Ključne besede: genski tok, genska fragmentacija, ISSR, dodelitev populaciji, Lallemantia.
Received: 23. 4. 2018

Revision received: 4. 9. 2018

Accepted: 4. 9. 2018

\begin{abstract}
Lallemantia royleana (Benth.) Benth. (Family Lamiaceae), is one of the most popular medicinal plants in Iran. It is an herbaceous pant that is commonly known as "Lady mantle". The vernacular name of Lallemantia royleana's seed is Balangu or Balangu Shirazi that is used as a source of medicine. Medicinal plants are very important from economic point of view in Iran and several large industries are focused on medicinal plants cultivation, extraction and export. Therefore, providing data on the biology of these plants is important for the country. Lallemantia royleana grows in different parts of Iran and forms several local populations. Genetic, morphological and biochemical divergence of geographical populations are well known in plant species. We have no report on population genetic structure, genetic fragmentation, local adaptation and gen flow of Lallemantia royleana populations in the country. Therefore, the present population genetics investigation was programmed to produce data on above said questions. Randomly collected plants of 7 geographical regions were studied by ISSR molecular markers. This information can be used in hybridization and gene conservation of this medicinal plant in Iran.

Izvleček

Lallemantia royleana (Benth.) Benth. (družina Lamiaceae) je ena najbolj priljubljenih zdravilnih rastlin v Iranu. To je zelnata rastlina, njena semena z domačim imenom Balangu ali Balangu Shirazi so uporabna v zdravilstvu. Zdravilne rastline so v Iranu tudi gospodarsko pomembne in številna velika industrijska podjetja se ukvarjajo z gojenjem zdravilnih rastlin, predelavo in njihovim izvozom. Zato so raziskave biologije the rastlin pomembne. Lallemantia royleana uspeva v različnih predelih $\mathrm{v}$ Iranu in ima številne lokalne populacije. Genetska, morfološka in biokemična raznolikost geografskih populacij je dobro znana. Ne obstajajo pa podatki o genetski strukturi, genetski fragmentiranosti, lokalnih prilagoditvah in genetskem toku med populacijami v Iranu. Zato $\mathrm{v}$ članku z raziskavo populacijske genetike poskušamo odgovoriti na zgornja vprašanja. Naključno vzorčene rastline iz sedmih geografskih območij smo preučili z ISSR molekularnimi markerji. To bo uporabno za križanje (hibridizacijo) in varstvo genetske raznolikosti te zdravilne vrste v Iranu.
\end{abstract}




\section{Introduction}

Geographically widely distributed plant species encounter various ecological conditions and variable altitudes. These taxa are subjected to different selection pressures and sometimes due to geographical barriers suffer from population fragmentation. In these situations, plants reveal morphological and genetic divergence in their local populations (see for example, Azizi et al. 2014, Sheidai et al. 2012, 2013, 2014, Minaeifar et al. 2015). Some medicinal species even reveal difference in their phytochemical compositions

Habitat fragmentation reduced the number of plant individuals in local populations, which in turn brings about inbreeding and reduced level of genetic diversity due to the act of genetic drift (Freeland et al. 2011). Due to medicinal and economic importance of medicinal plants, it is frequently used by local people. Therefore they become threatened by both habitat fragmentation (reduced genetic variability) and eradication by local inhabitants. Therefore we reveal a genetic investigation in geographical populations of medicinally important plant species Lallemantia royleana (Benth.) Benth. in Iran. The data obtained is important for conservation and germ plasm evaluation of this medicinal plant in the country.

Population genetics analyses provide valuable information about the levels of genetic variation, the partitioning of genetic variability within/between populations, gene flow, inbreeding, self-pollination versus outcrossing, effective population size and population bottleneck. The information obtained can help in developing effective management strategies for endangered and/or invasive species (Chen 2000, Ellis \& Burke 2007).

Lallemantia royleana (Benth.) is an annual herb of the genus Lallemantia L. (Family Lamiaceae) and is commonly known as "Lady mantle". The vernacular name of Lallemantia royleana's seed is Balangu or Balangu Shirazi (Naghibi et al. 2005). This species grows in Western Siberia, Central Asia, Xinjiang, Pakistan, Kashmir, Iran, Syria, Kazakhstan, Kyrgyzstan, Russia, Tajikistan, Turkmenistan, Uzbekistan, SW Asia, and Europe (Cao Shu 1994). Balangu is agood source of fiber, oil and protein and has medicinal, nutritional and human health properties (Naghibi et al. 2005). This natural herb is used for the treatment of arthritis, joint pain, rheumatism, osteoarthritis and abscesses inflammations. This seed absorb water quickly when soaked in water and produce a sticky, turbid and tasteless liquid. The Balangu seeds are used in a wide range of products made in traditional or industrial such as a beverage (namely Tokhme Sharbati) and bread in Iran and Turkey (Mazhe et al. 2012).
Different molecular markers have been used in population genetic studies. We used ISSR (Inter-simple sequence repeats) since these markers are reproducible, cheap, easy to work and are known to be efficient in population genetic diversity studies (Sheidai et al. 2012, 2013, 2014, Minaeifar et al. 2015).

\section{Material and methods}

\subsection{Plant material}

Seventy-four plant specimens of Lallemantia royleana were randomly collected from 7 geographical populations during 2014-2015 in Iran (Table 1, Figure1).

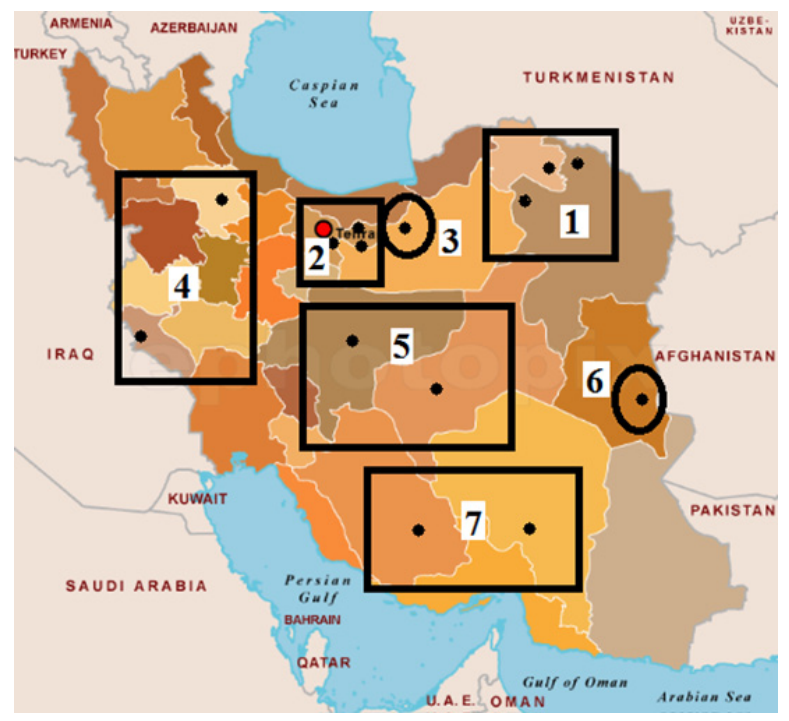

Figure 1: Distribution map of Lallemantia royleana populations. Slika 1: Karta razširjenosti populacij vrste Lallemantia royleana.

\subsection{DNA extraction and ISSR assay}

Fresh leaves were collected randomly in each of the studied populations and dried in silica gel powder. Genomic DNA was extracted using CTAB with activated charcoal protocol (Murry and Tompson, 1980). The quality of extracted DNA was examined by running on $0.8 \%$ agarose gel. Ten ISSR primers; (AGC)5GT, (CA)7GT, (AGC)5GG, UBC810, (CA)7AT, (GA)9C, UBC807, UBC811, (GA)9A and (GT)7CA commercialized by UBC (the University of British Columbia) were used.

PCR reactions were performed in a $25 \mu$ l volume containing $10 \mathrm{mM}$ Tris- $\mathrm{HCl}$ buffer at $\mathrm{pH} 8 ; 50 \mathrm{mM} \mathrm{KCl} ; 1.5$ $\mathrm{mM} \mathrm{MgCl} 2 ; 0.2 \mathrm{mM}$ of each dNTP (Bioron, Germany), $0.2 \mu \mathrm{M}$ of a single primer; $20 \mathrm{ng}$ genomic DNA and $3 \mathrm{U}$ of Taq DNA polymerase (Bioron, Germany). 
Table 1: Geographical populations in Lallemantia species.

Tabela 1: Geografske populacije vrst rodu Lallemantia.

\begin{tabular}{|c|c|c|c|c|c|c|}
\hline $\begin{array}{l}\text { Geographical } \\
\text { populations }\end{array}$ & Province & Locality & $\begin{array}{l}\text { Number of } \\
\text { individuals }\end{array}$ & Longitude & Latitude & $\begin{array}{c}\text { Altitude } \\
\text { (m) }\end{array}$ \\
\hline \multirow{3}{*}{1} & Razavi Khorasan & Sabzevar & 5 & N 36.124394 & E 57.392022 & 975 \\
\hline & north Khorasan & Esfarayen & 5 & N 37.043399 & E 57.303396 & 1253 \\
\hline & Razavi Khorasan & Dargaz & 5 & N 37.264024 & E 59.062901 & 477 \\
\hline \multirow{3}{*}{2} & Tehran & Varamin & 3 & N 35.192931 & E 51.385210 & 921 \\
\hline & Tehran & Ghiamdasht & 3 & N 35.312385 & E 51.390316 & 1032 \\
\hline & Tehran & Sorkhe Hesar & 2 & N 35.412883 & E 51.340322 & 1452 \\
\hline 3 & Semnan & Mahdishahr & 15 & N 35.424278 & E 53.211328 & 1667 \\
\hline \multirow{2}{*}{4} & Ilam & Ilam & 5 & N 33.181355 & E 46.370062 & 1110 \\
\hline & Zanjan & Zanjan & 5 & N 36.292310 & E 48.230727 & 1882 \\
\hline \multirow[b]{2}{*}{5} & Yazd & Hosein abad & 4 & N 32.025460 & E 54.140368 & 1136 \\
\hline & Esfahan & Esfahan & 10 & N 32.391909 & E 51.400089 & 1579 \\
\hline 6 & South Khorasan & & 6 & N 32.361815 & E 58.575615 & 1583 \\
\hline \multirow[t]{2}{*}{7} & Shiraz & Shiraz & 3 & N 28.292160 & E 53.337890 & 1050 \\
\hline & Kerman & Kerman & 3 & N 36.432337 & E 12.003355 & 66 \\
\hline
\end{tabular}

The amplifications' reactions were performed in Techne thermocycler (Germany) with the following program: 5 min initial denaturation step $94^{\circ} \mathrm{C}$, followed by $40 \mathrm{cy}$ cles of $1 \mathrm{~min}$ at $94^{\circ} \mathrm{C} ; 1 \mathrm{~min}$ at $57^{\circ} \mathrm{C}$ and $1 \mathrm{~min}$ at $72^{\circ} \mathrm{C}$. The reaction was completed by final extension step of 7 min at $72^{\circ} \mathrm{C}$. The amplification products were observed by running on $1 \%$ agarose gel, followed by the ethidium bromide staining. The fragment size was estimated by using a 100 bp molecular size ladder (Fermentas, Germany).

\subsection{Data analysis}

\subsubsection{Genetic diversity and population structure}

ISSR bands obtained were coded as binary characters (presence $=1$, absence $=0$ ). The genetic diversity parameters like, allele diversity (Weising et al. 2005), Nei's gene diversity $(\mathrm{H})$, Shannon information index (I), number of effective alleles, and percentage of polymorphism (Freeland et al. 2011), were determined for each population.

Nei's genetic distance was used for clustering (Weising et al. 2005, Freeland et al. 2011). Neighbor Joining (NJ), UPGMA (Unweighted Paired Group using average) clustering and Neighbor-Net method of networking was used for grouping after 100 times bootstrapping/ permutations (Freeland et al. 2011, Huson \& Bryant 2006). The
Mantel test was performed to check correlation between geographical and the genetic distances of the studied populations (Podani 2000). PAST ver. 2.17 (Hammer et al. 2012) programs was used for these analyses. Pearson coefficient of correlation was determined between geographical features (altitude, longitude and latitude) and genetic diversity parameters.

AMOVA (Analysis of molecular variance) test (with 1000 permutations) as implemented in GenAlex 6.4 (Peakall \& Smouse 2006), and Nei's Gst analysis of GenoDive ver.2 (2013) (Meirmans \& Van Tienderen, 2004), were used to reveal significant genetic difference among the studied populations (Sheidai et al. 2014).

The population genetic differentiation was studied by G'st_est $=$ standardized measure of genetic differentiation (Hedrick 2005), and D_est = Jost measure of differentiation (Jost 2008). In order to overcome potential problems caused by the dominance of ISSR markers, a Bayesian program, Hickory (ver. 1.0) (Holsinger \& Lewis 2003), was used to estimate parameters related to genetic structure (theta B value) (Tero et al. 2003).

Bayesian based model STRUCTURE analysis (Pritchard et al. 2000), and maximum likelihood-based method of K-Means clustering were used to study the genetic structure of populations (Sheidai et al. 2014). For STRUCTURE analysis, data were scored as dominant markers (Falush et al. 2007). The Evanno test (Evanno et al. 2005) and K-Means clustering were used to iden- 
tify optimum k genetic groups (Sheidai et al. 2014). Two summary statistics, 1- pseudo-F and 2- Bayesian Information Criterion (BIC) provide the best fit for $\mathrm{k}$ (Meirmans 2012).

\subsection{Gene flow}

Gene flow was determined by different approaches. 1Calculating $\mathrm{Nm}$ an estimate of gene flow from Gst by PopGene ver. 1.32 (1997) as: $\mathrm{Nm}=0.5(1-\mathrm{Gst}) / \mathrm{Gst}$. This approach considers equal amount of gene flow among all populations. 2- Population assignment test based on maximum likelihood as performed in Genodive ver. in GenoDive ver. 2. (2013).

We used the statistical model called latent factor mixed models (LFMM) to check if ISSR markers show correlation with environmental features (longitude, latitude, and altitude) of the studied populations. The analysis was done by LFMM program version: 1.2 (Frichot et al. 2013).

\section{Results}

\subsection{Genetic diversity}

Genetic diversity parameters determined in the studied populations are presented in Table 2 . The highest value for gene diversity occurred in populations 1 and 7 (0.193 and 0.188 , respectively). The highest level of genetic polymorphism (75.41) occurred in population 1, while the lowest value of the same occurred in population 6 (36.07).

The Mantel test produced significant correlation between geographical distance and genetic distance of the studied populations $(\mathrm{r}=0.23, \mathrm{P}<0.01)$. This indicated the occurrence of isolation by distance (IBD) among populations and that close-bye located populations have greater chance of gene flow compared to those located far from each other.

However, detailed analysis of geographical features revealed a more complex relationship between genetic variability and geographical features.

The latitude was positively correlated with the Nei gene diversity $(r=0.53, P=0.20)$, and genetic polymorphism $(r=0.74, P<0.05)$. The altitude showed significant negative correlation with gene diversity $(\mathrm{r}=-0.81, \mathrm{P}<0.05)$, and the genetic polymorphism $(\mathrm{r}=-0.74, \mathrm{P}<0.05)$. The longitude was negatively correlated with the gene diversity $(r=-0.33,(P>0.05)$, and positively correlated with as the genetic polymorphism $(r=-0.08, \mathrm{P}>0.05)$.

\subsection{Population genetic structure}

AMOVA (Table3) produced significant genetic difference (PhiPT $=0.29, \mathrm{P}=0.001)$ among the studied populations. It also revealed that $29 \%$ of total genetic variability occurred among the studied populations while, $71 \%$ occurred within these populations.

Pairwise AMOVA produced significant difference among these populations. Hickory test also produced high Theta B value (0.30) supporting AMOVA.

Gst $(0.32, P=0.001)$, Hedrick standardised fixation index $\left(\mathrm{G}^{\prime}\right.$ st $\left.=0.38, \mathrm{P}=0.001\right)$ and Jost differentiation index (D-est $=0.12, \mathrm{P}=0.001)$, revealed that the studied populations are genetically differentiated.

UPGMA and NJ clustering as well as Neighbor-Net produced similar results, therefore, the UPGMA tree is presented and discussed (Figure 2). UPGMA tree produced three major clusters. Most of the plants in each population were placed close to each other, but some were placed intermixed with the other populations.

Table 2: Genetic diversity parameters in Lallemantia royleana populations.

Tabela 2: Genetska raznolikost populacij vrste Lallemantia royleana.

\begin{tabular}{lrrrccccc} 
Pop & $\mathrm{N}$ & $\mathrm{Na}$ & $\mathrm{Ne}$ & $\mathrm{I}$ & $\mathrm{He}$ & $\mathrm{UHe}$ & $\% \mathrm{P}$ & $\mathrm{Hs}$ \\
Pop1 & 15 & 1.525 & 1.310 & 0.305 & 0.193 & 0.199 & 75.41 & 0.248 \\
Pop2 & 8 & 0.836 & 1.163 & 0.168 & 0.106 & 0.113 & 37.70 & 0.161 \\
Pop3 & 15 & 1.148 & 1.232 & 0.233 & 0.147 & 0.153 & 54.10 & 0.191 \\
Pop4 & 10 & 0.934 & 1.228 & 0.204 & 0.135 & 0.142 & 40.98 & 0.164 \\
Pop5 & 14 & 1.344 & 1.270 & 0.271 & 0.171 & 0.178 & 63.93 & 0.24 \\
Pop6 & 6 & 0.869 & 1.181 & 0.172 & 0.111 & 0.122 & 36.07 & 0.165 \\
Pop7 & 6 & 1.016 & 1.334 & 0.275 & 0.188 & 0.205 & 47.54 & 0.236 \\
\hline
\end{tabular}

$\mathrm{Na}=$ No. of alleles, $\mathrm{Ne}=$ No. of effective alleles, $\mathrm{I}=$ Shanon Information Index, $\mathrm{He}=\mathrm{Nei}$ ' gene diversity, $\mathrm{UHe}=$ Unbiased Nei' gene diversity, \%P = Percentage of polymorphism, Hs = Genetic diversity due to sub-populations (Populations 1-7 are according to Table 1). 


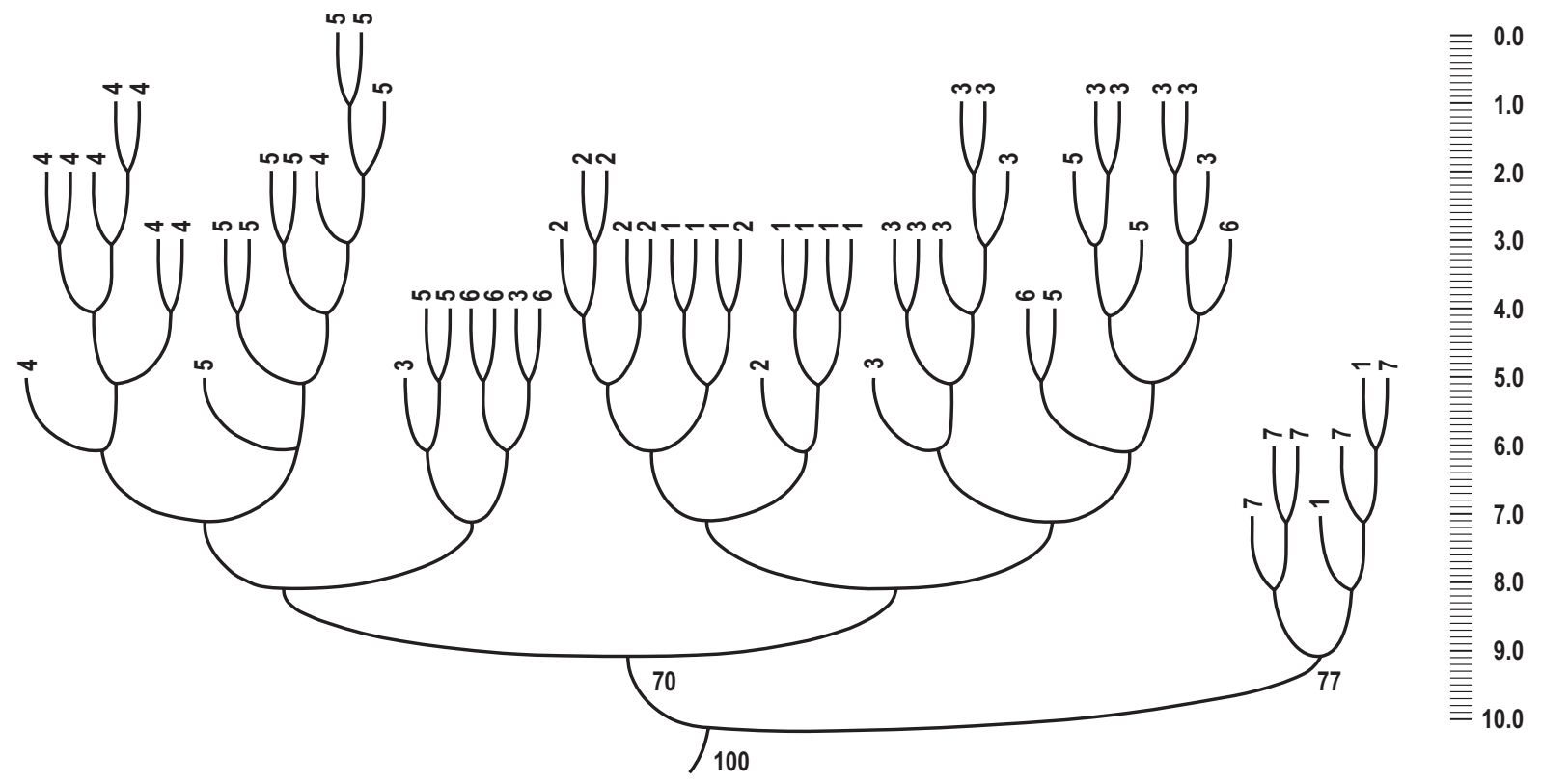

Figure 2: UPGMA dendrogram of Lallemantia royleana populations (populations 1-7 are according to Table 1). Slika 2: Dendrogram UPGMA populacij vrste Lallemantia royleana (populacije 1-7 so enake kot v Tabeli 1).

Plants of populations 4 and 5 formed the first cluster, while plants of populations $1-3$ and 6 comprised the second cluster. Plants of populations 7 were placed in the third cluster, which joined the other two clusters with some distance.



Figure 3: MDS plot of the studied Lallemantia royleana populations (populations 1-7 are according to Table 1).

Slika 3: Graf analize MDS preučevanih populacij vrste Lallemantia royleana (populacije 1-7 so enake kot v Tabeli 1). 
Evanno test performed on STRUCTURE analysis and pseudo-F index of K-Means clustering produced optimum number of $\mathrm{k}=2$. These results indicated that we have 2 genetic groups in the studied populations. STRUCTURE plot (Figure 4) based on $\mathrm{k}=2$, identified these two genetic groups (gene pools).

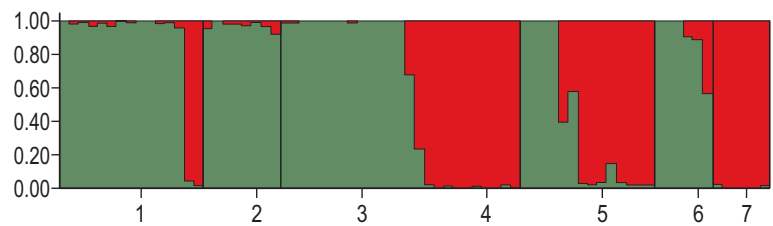

Figure 4: STRUCTURE plot of the studied Lallemantia royleana populations (populations 1-7 are according to Table 1).

Figure 4: Graf analize STRUCTURE preučevanih populacij vrste Lallemantia royleana (populacije 1-7 so enake kot v Tabeli 1).

The STRUCTURE plot obtained based on admixture model and Bayesian approach revealed that populations 1,2 and 3 are genetically more alike and comprise the first gene pool, populations 4,5 and 6 are genetically more alike and comprise the second gene pool while population 7 formed the third gene pool. More than half of individuals from population 5 shares alels with 2 gene pools.

This plot also revealed low degree of genetic admixture between the 3 gene pools, for example some plants in populations 1 and 6 had shared alleles with members of the populations 4 and 7 .

\subsection{Gene flow}

We used different indirect approaches to study the level of gene flow or ancestral shared alleles in Lallemantia royleana populations. These approaches are based on different assumptions and mathematical models. The $\mathrm{Nm}$ approach assumes equal rate of gene flow among populations that might not be true always. The NM analysis produced mean $\mathrm{Nm}=1.00$, that indicate a low degree of gene flow among populations. The ISSR loci varied in their $\mathrm{Nm}$ value from 0.20 to 19.30 .

This result is in agreement with STRUCTURE result presented before. Most of the 74 ISSR loci studied, had high $\mathrm{Nm}$ value $(>1.00)$. These loci were exchanged more frequently among the studied populations, while the other loci were private loci and were confined to one or more local populations.

More detailed information was obtained by population assignment test (Table 4). In this approach, the assignment of current plant to the inferred population is determined by maximum likelihood method (Meirmans \& Van Tienderen 2004).
The assignment test revealed that some plants in populations 1 are closer to the population 3 and 7 . The same holds true for plants of populations 3 and 5, and 7 as well as 5 and 6 . Therefore, population assignment test also revealed some degree of gene flow among populations of the second gene pool.

LFMM analysis revealed that out of 75 ISSR loci, 16 are adaptive. Some of these ISSR loci had low $\mathrm{Nm}$ value $(<1)$ and are private alleles, for example, ISSR loci 2, 4, 5, 37, 48 , and 49. The other loci had high $\mathrm{Nm}$ value $(>1.0)$ and were more frequently shared by the studied populations.

\section{Discussion}

traditional medicine is widely practiced in Iran and therefore, medicinal plants cultivation and conservation are very important in the country. Many companies are focused on medicinal plants cultivation, extraction and export.

Lallemantia royleana is one of the most popular medicinal plants in Iran and is extensively consumed by locals. Therefore, it is threatened in natural habitats. In order to conserve this valuable plant species, it is necessary to monitor the size of its natural populations and study their level of genetic variability as well as population genetic fragmentation.

Population fragmentation in general reduces the rate of gene flow and increases the genetic differentiation of populations. In such case, the genetic drift becomes active and reduces the within-population genetic variability (Setsuko et al. 2007, Hou \& Lou 2011). In the present study, AMOVA revealed that Lallemantia royleana populations are genetically differentiated but contain high level of interpopulation genetic variability $(71 \%$ of their total genetic variation). This should be due to outcrossing nature of this species. High genetic diversity is very important for the continuity of the plant species and their adaptation to fluctuating environmental conditions (Çalişkan 2012). Moreover, gene flow among populations introduces new genes in to the local populations and increases their genetic variability (Hou \& Lou 2011, Sheidai et al. 2014). In the present study, both STRUCTURE plot and population assignment test revealed the occurrence of gene flow among the studied Lallemantia royleana populations for example population 4 is located in the western part of the country, while population 7 is located in southern part, with great distance from each other. The location of population 5 is somewhat in the central parts of the country and between the other populations and may be in contact with all these populations. This may be the reason that plants of this population showed the presence of alleles from the populations 4 
and 7 and also from the other studied populations. This can bring about enough genetic variability for this medicinal plant species within the country.

Population genetic studies, also provides insight about population adaptive differences that have been developed between plants from different regions (Waples 1998). Populations' genetic differences with presumed potential adaptive value can be used in conservation strategies (Sheidai et al. 2012, 2013, 2014). LFMM analysis identified some of the ISSR loci with potential adaptive value.

The Mantel test revealed a pattern of isolation-by distance across the distribution range of the studied Lallemantia royleana populations. It suggested that the dispersal of these populations might be constrained by distance, and gene flow is most likely to occur between neighboring populations. As a result, more closely situated populations tend to be more genetically similar to one another (Slatkin 1993, Hutchison \& Templeton 1999, Medrano \& Herrera 2008). The STRUCTURE analysis identified three different gene pools for Lallemantia royleana in Iran. These gene pools have their own specific alleles and may be used in conservation and hybridization programs.

Lallemantia royleana populations showed a general trend of negative association between altitude and gene diversity as well as the genetic polymorphism. The altitude is an important factor for population genetic differentiation (Ohsawa \& Ide 2008, Di et al. 2014, Noormohammadi et al. 2015). Populations not only are differentiated on mountains along vertical axes, but genetic changes can also occur along horizontal axes. For instance, ridges may provide geographical barriers to gene flow between populations on their opposite sides, so genetic differentiation may occur across ridges (Taberlet et al. 1998).

However, some studies also reported no differentiation between populations at low and high altitudes (Ohsawa et al. 2007), due to the overlap of flowering phenology in populations at different altitudes, species' extensive pollen flow, and long-distance seed dispersal between different altitudes by animals, particularly birds.

In conclusion, the present study indicates that genetic divergence, limited gene flow and local adaptation have played role in diversification of Lallemantia royleana populations in Iran. These findings may be of use in conservation this medicinal plant in the country.

\section{Acknowledgment}

We thank Dr. Farrokh Ghahremani-Nejad for allowing us to use Herbarium of KharazmiUniversity, Tehran.

Masoud Sheidai (D, https://orcid.org/0000-0003-3983-6852

\section{References}

Azizi, N., Sheidai, M., Mozafarian, V. \& Noormohammadi, Z. 2014:

Genetic, cytogenetic and morphological diversity in Helicrysum leucocephalum (Asteraceae) populations. Biologia 69: 566-573

Çalişkan, M. 2012: Genetic Diversity in Plants Edited by, ISBN 978953-51-0185-7, 510 pages, Publisher, In: Tech, Chapters published under CC BY 3.0 license.

Cao Shu, B. (Eds.) 1994: Lallemantia L., Flora of China, Lamiaceae. 17: 133-134.

Chen, X.Y. 2000: Effects of fragmentation on genetic structure of plant populations and implications for the biodiversity conservation. Acta Ecologica Sinica 20: 884-892.

Di, X.Y., Liu K.W., Hou S.Q., Ji, P.L. \& Wang, Y. 2014: Genetic variation of hazel (Carylusheterophylla) populations at different altitudes in Xingtagsi forest park in Huoshan, Shanxi, China. Plant omics journal 7: 213-220.

Ellis, J.R. \& Burke, J.M. 2007: EST-SSRs as a resource for population genetic analyses. Heredity 99:125-132.

Freeland, J.R., Kirk, H. \& Peterson, S.D. 2011: Molecular Ecology. Wiley-Blackwell, U.K. (2nd Edition), 449.

Frichot, E., Schoville, S.D., Bouchard, G. \& Francois, O. 2013: Testing for associations between loci and environmental gradients using latent factor mixed models. Molecular Biology and Evolution 30: $1687-1699$

Hammer, Ø., Harper, D.A.T. \& Ryan, P.D. 2012: PAST: Paleontological Statistics software package for education and data analysis. Palaeontologia Electronica 4: 9.

Hedrick, P.W. 2005: A standardized genetic differentiation measure. Evolution 59:1633-1638.

Hou, Y. \& Lou, A. 2011: Population Genetic Diversity and Structure of a Naturally Isolated Plant Species, Rhodiola dumulosa (Crassulaceae). PLoS ONE6, e24497.

Huson, D.H. \& Bryant, D. 2006: Application of Phylogenetic Networks in Evolutionary Studies. Molecular Biology and Evolution 23: 254-267.

Meirmans, P.G. 2012: AMOVA-based clustering of population genetic data. Journal Heredity 103: 744-750.

Meirmans, P.G. \& Van Tienderen, P.H. 2004: GENOTYPE and GENODIVE: two programs for the analysis of genetic diversity of asexual organisms. Molecular Ecology Notes 4: 792-794.

Minaeifar, A.A., Sheidai, M., Attar, F., Noormohammadi, Z. \& Ghasemzadeh-Baraki B. 2015: Genetic and morphological diversity in Cousinia tabrisiana (Asteraceae) populations. Biologia 70: 328-338.

Murry, M.G. \& Tompson, W.F.1980: Rapid isolation of high molecular weight plant DNA. Nucleic Acid Resear 8: 4321-4325.

Naghibi, F., Mosaddegh, M., Motamed, Ms. \& Ghorbani, A. 2005: Labiatae family in folk medicine in Iran from ethnobotany to pharmacology. Iranian Journal of Pharmaceutical Research 2: 63-79.

Noormohammadi, Z., Shafaf, T., Farahani, F., Sheidai, M., Talebi, S.M. \& Hasheminejad- Ahangarani- Farahani, Y. 2015: Within and among genetic variation in Asia flax Linum austriacum (Linaceae) in response to latitude change. Cytogenetic and molecular analyses 16: 145-150. 
Ohsawa, T., Tsuda, Y., Saito, Y., Sawada, H. \& Ide, Y. 2007:

Altitudinal Genetic Diversity and Differentiation of Quercus crispula in the Chichibu Mountains, Central Japan. International Journal of

Plant Sciences 168: 333-340

Ohsawa, T. \& Ide Y. 2008: Global patterns of genetic variation in plant species along vertical and horizontal gradients on mountains. Global Ecol. Biogeog 17: 152-163.

Peakall, R. \& Smouse, P.E. 2006: GENALEX 6: genetic analysis in Excel. Population genetic software for teaching and research. Molecular Ecology Notes 6: 288-295.

Podani, J. 2000: Introduction to the Exploration of Multivariate Data, Leide, Netherlands, Backhuyes,

Setsuko, S., Ishida, K., Ueno, S., Tsu Mura, Y. \& Tomaru, N. 2007: Population differentiation and gene flow within a metapopulation of a threatened tree, Magnolia stellata (Magnoliaceae). American Journal of Botany 94: 128-136.

Sheidai, M., Zanganeh, S., Haji-Ramezanali, R., Nouroozi, M., Noormohammadi, Z. \& Ghsemzadeh-Baraki, S. 2013: Genetic diversity and population structure in four Cirsium (Asteraceae) species. Biologia 68: 384-397.
Sheidai, M., Ziaee, S., Farahani, F., Talebi, S.M., Noormohammadi, Z. \& Hasheminejad-Ahangarani Farahani, Y. 2014: Infra-specific genetic and morphological diversity in Linum album (Linaceae). Biologia 69: 32-39.

Sheidai, M., Seif, E., Nouroozi, M. \& Noormohammadi, Z. 2012: Cytogenetic and molecular diversity of Cirsium arvense (Asteraceae) populations in Iran. Journal of Japanese Botany 87: 193-205.

Slatkin, M. 1993: Isolation by distance in equilibrium and nonequilibrium populations. Evolution 47: 264-279.

Taberlet, P., Fumagalli, L. \& Wust- Saucy, A.G. 1998: Comparative phylogegraphy and postgavial colonization routes in Europe. Molecular Ecology 7: 453-464.

Waples, R.S. 1998: Separating the wheat from the chaff patterns of genetic differentiation in high gene flow species. The American Genetic Association 89: 438-450.

Weising, K., Nybom, H., Wolff, K. \& Kahl, G. 2005: DNA Fingerprinting in Plants. In: Boca Rayton, F.l. (eds.), Principles, Methods, and ApplicationsCRC Press, USA, 4pp. 72. 